\title{
Effect of Microwave Sintering on the Microstructure and Dielectric Properties of $\mathrm{Bi}_{2} \mathrm{O}_{3}$-Doped $\left(\mathrm{Ba}_{0.6} \mathrm{Sr}_{0.4}\right)\left(\mathrm{Ti}_{0.94} \mathrm{Cu}_{0.06}\right) \mathrm{O}_{3}$ Ceramics
}

\author{
Yue-Lin Li ${ }^{1}$, Ta-Chih Cheng ${ }^{2}$, Ying-Chieh Lee ${ }^{{ }^{*}}$ \\ ${ }^{1}$ Department of Materials Engineering, National PingTung University of Technology \& Science, Ping-Tung, Taiwan; ${ }^{2}$ Department of \\ Tropical Agriculture and Intl. Cooperation, National PingTung University of Technology \& Science, Ping-Tung, Taiwan. \\ Email: ${ }^{\text {YCLee@mail.npust.edu.tw }}$
}

Received November 24 $4^{\text {th }}, 2013$; revised December 21 ${ }^{\text {st }}$ 2013; accepted December $26^{\text {th }}, 2013$

Copyright (C) 2014 Yue-Lin Li et al. This is an open access article distributed under the Creative Commons Attribution License, which permits unrestricted use, distribution, and reproduction in any medium, provided the original work is properly cited. In accordance of the Creative Commons Attribution License all Copyrights (C) 2014 are reserved for SCIRP and the owner of the intellectual property Yue-Lin Li et al. All Copyright (C) 2014 are guarded by law and by SCIRP as a guardian.

\section{ABSTRACT}

The effects of microwave sintering on the sintering behaviour, microstructure and dielectric properties of $\mathrm{Bi}_{2} \mathrm{O}_{3}$ doped $\left(\mathrm{Ba}_{0.6} \mathrm{Sr}_{0.4}\right)\left(\mathrm{Ti}_{0.94} \mathrm{Cu}_{0.06}\right) \mathrm{O}_{3}$ (BSTC) ceramics were investigated. The microstructure and dielectric properties of a BSTC ceramic were also studied given different amounts of $\mathrm{Bi}_{2} \mathrm{O}_{3}$ doping. Microwave heating with sintering temperatures below $1000^{\circ} \mathrm{C}$ significantly improves the densification of $\mathrm{Bi}_{2} \mathrm{O}_{3}$-doped $\mathrm{BSTC}$ ceramics. The BSTC ceramic with $1 \mathrm{wt} \% \mathrm{Bi}_{2} \mathrm{O}_{3}$ addition sintered at $950{ }^{\circ} \mathrm{C}$ in air for $30 \mathrm{~min}$ exhibited dielectric properties of $\varepsilon_{r}$ $=3756$, dielectric loss of $\tan \delta=7 \times 10^{-3}$ and bulk density $>96 \%$ of theoretical density.

\section{KEYWORDS}

$\left(\mathrm{Ba}_{0.6} \mathrm{Sr}_{0.4}\right)\left(\mathrm{Ti}_{0.94} \mathrm{Cu}_{0.06}\right) \mathrm{O}_{3}$ (BSTC); Dielectric Properties; Microwave Sintering; Microstructures

\section{Introduction}

It is well known that barium and strontium titanates (Ba$\mathrm{TiO}_{3}$ and $\mathrm{SrTiO}_{3}$ ) can be formed by the solid solutions because of their identical crystal structures and the comparable ionic radii of $\mathrm{Ba}^{2+}$ and $\mathrm{Sr}^{2+}$ [1-4]. This material is very promising for practical applications, such as phase shifter, delay lines, tunable filters, steerable antennas, etc. [5-7]. However, an ideal BST $\left(\mathrm{BaSrTiO}_{3}\right)$ system should exhibit the following characteristics: high dielectric constant $\left(\varepsilon_{\mathrm{r}}\right)$, low dissipation factor $(\tan \delta)$, large tunability and a low temperature dependence $[5,6,8]$.

Pure BST ceramics have to be sintered at $\sim 1350^{\circ} \mathrm{C}$, a temperature range much higher than the melting point of conductors such as $\mathrm{Ag}\left(961^{\circ} \mathrm{C}\right)$ or $\mathrm{Cu}\left(1083^{\circ} \mathrm{C}\right)$. Therefore, only platinum or refractory metals can be used as inner conductors [7]. These materials are expensive, their electrical performance is poor, and the cost-effective fabrication of high-quality components is difficult. Several methods are commonly used for lowering the sintering

${ }^{*}$ Corresponding author. temperature of dielectric ceramics, such as: the addition of glass; chemical pre-treatment and processing of ceramic powders; and the addition of small particles of starting materials [9-11]. Of these three methods, liquidphase sintering with glass addition is generally known to be the most effective and the least expensive way of achieving high density sintered ceramics $[12,13]$.

Researchers have already reported attempts to decrease the sintering temperature of BST to $900^{\circ} \mathrm{C}$ so that it can be used in LTCC (Low temperature cofiring ceramics) applications. Rhim et al. [9] reported on the influence of $\mathrm{B}_{2} \mathrm{O}_{3}$ additions on the sintering temperature of commercial $\mathrm{Ba}_{0.7} \mathrm{Sr}_{0.3} \mathrm{TiO}_{3}$; they showed that the addition of $0.5 \mathrm{wt} \% \mathrm{~B}_{2} \mathrm{O}_{3}$ reduces the sintering temperature to $1150^{\circ} \mathrm{C}$, while the dielectric ferroelectric properties remain unchanged. Valant et al. [14] reported on the influence of $\mathrm{Li}_{2} \mathrm{O}$ additions on the sintering temperature of $\mathrm{Ba}_{0.6} \mathrm{Sr}_{0.4} \mathrm{TiO}_{3}$; they showed that an addition of only 0.4 wt\% $\mathrm{Li} 2 \mathrm{O}$ to $\mathrm{Ba}_{0.6} \mathrm{Sr}_{0.4} \mathrm{TiO}_{3}$ powder was able to reduce the sintering temperature to $\leq 900^{\circ} \mathrm{C}$ and produce ceramics with a relative density of $97 \%$. 
Microwave sintering is a method of internal self-heating through the absorption of microwave power. Therefore, internal microwave sintering can be compared with external sintering by thermal conduction or radiation. Microwave sintering is expected to produce a fine grain, a high degree of uniformity and high densification in ceramics, along with improving electrical and mechanical properties [15].

This experiment is based on $\left(\mathrm{Ba}_{0.6} \mathrm{Sr}_{0.4}\right)\left(\mathrm{Ti}_{0.94} \mathrm{Cu}_{0.06}\right) \mathrm{O}_{3}$ (BSTC) because of its low $T_{c}$, high dielectric constant, relatively low loss tangent, and good tunability. In a previous study [16], the dielectric constant of

$\left(\mathrm{Ba}_{0.6} \mathrm{Sr}_{0.4}\right)\left(\mathrm{Ti}_{0.94} \mathrm{Cu}_{0.06}\right) \mathrm{O}_{3}$ ceramics sintered at $1150^{\circ} \mathrm{C}$ was determined as 4094. However, the sintering temperature of $1150^{\circ} \mathrm{C}$ is still too high for LTCC applications. To reduce sintering temperature, the $\mathrm{Bi}_{2} \mathrm{O}_{3}$ was added in BSTC ceramics as a sintering aid. On the other hand, to decrease the volatility of the bismuth elements during sintering, the microwave process was employed to sinter $\mathrm{Bi}_{2} \mathrm{O}_{3}$-doped BSTC ceramics. In this paper, we examined the effects of microwave sintering on the sintering behaviour, microstructure and dielectric properties of $\mathrm{Bi}_{2} \mathrm{O}_{3}$-doped BSTC ceramics.

\section{Experimental Procedure}

Conventional ceramic fabrication processes were used to prepare the present BSTC samples from commercial powders of $\mathrm{BaCO}_{3}, \mathrm{SrCO}_{3}, \mathrm{CuO}$ and $\mathrm{TiO}_{2}$. The $\mathrm{BaCO}_{3}$, $\mathrm{SrCO}_{3}, \mathrm{TiO}_{2}$, and $\mathrm{CuO}$ powders were mixed with deionized water for $24 \mathrm{~h}$ in a $\phi 2 \mathrm{~mm}$ zirconia ball-mill. The mixture was dried, calcined at $1100^{\circ} \mathrm{C}$ for $6 \mathrm{~h}$ in air, and then crushed into a powder. An appropriate amount of $\mathrm{Bi}_{2} \mathrm{O}_{3}$ was mixed with the BSTC powders using the same procedure. The powders were mixed with the binder (Polyvinyl alcohol; PVA) additive and then were pressed into disk-shaped specimens. The samples were sintered in air by microwave processing, ramping at $30^{\circ} \mathrm{C} / \mathrm{min}$. The temperature of the sample was monitored with a type-R thermocouple shielded with platinum foil and grounded to the inner metallic wall of the microwave furnace. The samples were sintered at various temperatures from $900^{\circ} \mathrm{C}$ to $1000^{\circ} \mathrm{C}$, held for $30 \mathrm{~min}$ at the peak temperature. Samples were microwave sintered using a single-mode microwave furnace with a cavity of $37 \mathrm{~cm} \times$ $34.5 \mathrm{~cm} \times 33.5 \mathrm{~cm}$. The microwave sintering experiments were conducted in a $2.4 \mathrm{~kW}, 2.45 \mathrm{GHz}$. The samples were encased in a microwave susceptor ( $\mathrm{SiC}$ ) located in a thermal insulation package in the microwave chamber. Sintering temperature is measured using an optical pyrometer (President Honor industries Co., Ltd., Taiwan) focused directly onto the samples. The model of optical pyrometer is SH60 which can be applied at $600^{\circ} \mathrm{C}$ - $1200^{\circ} \mathrm{C}$. The pyrometer is directly connected to the controller and does not influence or interfere with the microwave field distribution within the cavity. However, the traditional metal thermocouples can interfere with the microwave field within the cavity preventing accurate measurements from being made. The optical pyrometer was calibrated at several temperature points using a type B PtRh thermocouple placed in contact with the samples.

The crystalline phases of the sintered ceramics were identified by X-ray diffraction pattern analysis (XRD, Bruker D8A, Germany) using Cu-K $\alpha$ radiation for $2 \theta$ from $20^{\circ}$ to $80^{\circ}$. The diffraction spectra were collected at a scan rate of $2.5^{\circ} / \mathrm{min}$. Microstructural observation of the sintered ceramics was performed using a scanning electron microscope (SEM, JEOL. JEL-6400 Japan) equipped with energy-dispersive spectroscopy (EDS). The bulk density of the sintered pellets was measured using the Archimedes method. Particle size was measured using a particle size analyzer (Malvern, Mastersizer 2000, UK). The capacitance and dissipation factor were measured at $1 \mathrm{MHz}$ and $23^{\circ} \mathrm{C}(\mathrm{HP} 4278 \mathrm{~A})$. The dielectric properties of the samples were measured as a function of temperature using a HP 4284A LCR meter and programmable temperature chamber interfaced to a PC for automated measurements, and samples were measured at temperatures ranging from $-55^{\circ} \mathrm{C}$ to $125^{\circ} \mathrm{C}$.

\section{Results and Discussion}

Before you begin to format your paper, first write and save the content as a separate text file. Keep your text and graphic files separate until after the text has been formatted and styled. Do not use hard tabs, and limit use of hard returns to only one return at the end of a paragraph. Do not add any kind of pagination anywhere in the paper. Do not number text heads-the template will do that for you.

Finally, complete content and organizational editing before formatting. Please take note of the following items when proofreading spelling and grammar:

\subsection{Phase Evolution in the Sintered Ceramics}

This study aims to find a way to reduce the sintering temperature of BSTC. The influence of $\mathrm{Bi}_{2} \mathrm{O}_{3}$ on the microstructural characteristics and dielectric properties was studied. The interaction of $\mathrm{Bi}_{2} \mathrm{O}_{3}$ with BSTC after microwave heating was investigated using $\mathrm{X}$-ray diffraction. Figure 1 shows the $\mathrm{X}$-ray diffraction spectra for the assintered BSTC ceramics with $1 \mathrm{wt} \% \mathrm{Bi}_{2} \mathrm{O}_{3}$ addition, sintered in air for $30 \mathrm{~min}$ at temperatures ranging from 900 to $1000^{\circ} \mathrm{C}$. All the samples are composed of a single phase, indicating that $\mathrm{Bi}_{2} \mathrm{O}_{3}$ did not form a crystalline phase for composition doped with $1.0 \mathrm{wt} \% \mathrm{Bi}_{2} \mathrm{O}_{3}$. It has been reported that the BST phase has high dielectric con- 


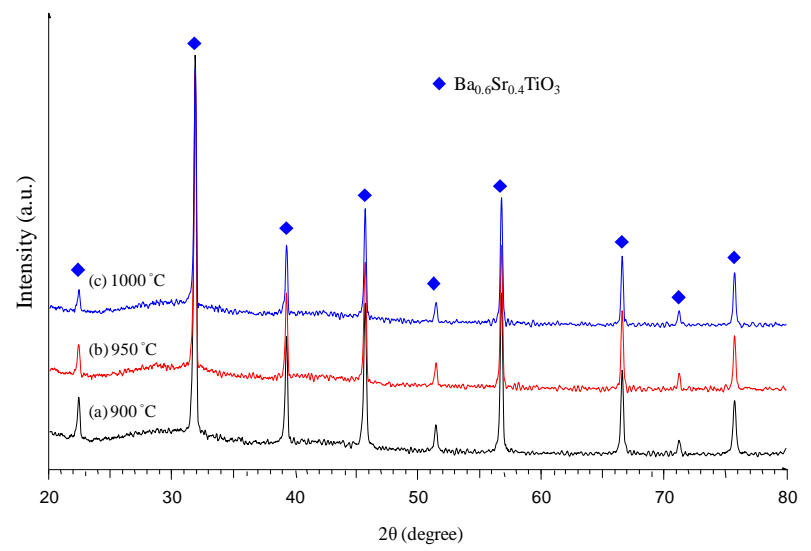

Figure 1. X-ray diffraction spectra of BSTC ceramics doped with $1 \mathrm{wt} \% \mathrm{Bi}_{2} \mathrm{O}_{3}$ sintered at (a) $900^{\circ} \mathrm{C}$, (b) $950^{\circ} \mathrm{C}$ and (c) $1000^{\circ} \mathrm{C}$.

stants, low dielectric losses, high tunability $[5,8,17]$ and could be suitable for use in dielectric resonators at microwave frequencies. Figure 2 shows the XRD patterns of the BSTC ceramics with different $\mathrm{Bi}_{2} \mathrm{O}_{3}$ addition at $950^{\circ} \mathrm{C}$. For $0.5 \mathrm{wt} \%, 1 \mathrm{wt} \%$ and $2 \mathrm{wt} \% \mathrm{Bi}_{2} \mathrm{O}_{3}$ doped BSTC ceramics, as shown in Figures 2(a)-(c), it was determined that there is a single crystalline phase of BST present in the specimen. For BSTC ceramics with $3 \mathrm{wt} \%$ $\mathrm{Bi}_{2} \mathrm{O}_{3}$ addition, as shown in Figure 2(d), it was found that the major crystalline phase is the same as BSTC ceramics doped with lower $\mathrm{Bi}_{2} \mathrm{O}_{3}$ content ( $\leq 2 \mathrm{wt} \%$ ). However, $\mathrm{CuBi}_{2} \mathrm{O}_{4}$ of minor impurity phases was detected in the specimens.

Figure 3 shows the variation of the lattice parameter as a function of the addition of $\mathrm{Bi}_{2} \mathrm{O}_{3}$ sintered at $950^{\circ} \mathrm{C}$. With increasing levels of $\mathrm{Bi}_{2} \mathrm{O}_{3}$ addition, the lattice constant initially increased suddenly, then kept approximately a constant. This result shows that a small amount of $\mathrm{Bi}_{2} \mathrm{O}_{3}$ addition led to $\mathrm{Cu}^{2+}$ precipitation from the grain in BSTC materials. When $\mathrm{Cu}$ substitutes into Ti sites in the perovskite $\mathrm{ABO}_{3}$ structure, it creates lattice strain and oxygen vacancies [18]. Therefore, the lattice parameter, $a$, of BSTC is smaller than the lattice parameter of BST.

\subsection{Microstructural Evolution in the Sintered Ceramics}

SEM micrographs of the BSTC specimens sintered at $950^{\circ} \mathrm{C}$ with $0,0.5,1$, and $3 \mathrm{wt} \%$ of $\mathrm{Bi}_{2} \mathrm{O}_{3}$ are shown in Figures 4(a)-(d), respectively. The images show that significant densification of BSTC ceramics with $\mathrm{Bi}_{2} \mathrm{O}_{3}$ dopant occurred. It is widely accepted that pure BSTC ceramic has to be sintered at $1150^{\circ} \mathrm{C}$ for several hours [16]. Therefore these results show that a small amount of $\mathrm{Bi}_{2} \mathrm{O}_{3}$ dopant can increase the density of BSTC ceramics with microwave firing at $950^{\circ} \mathrm{C}$. These SEM images confirm that the ceramics are sintered to a high density. The

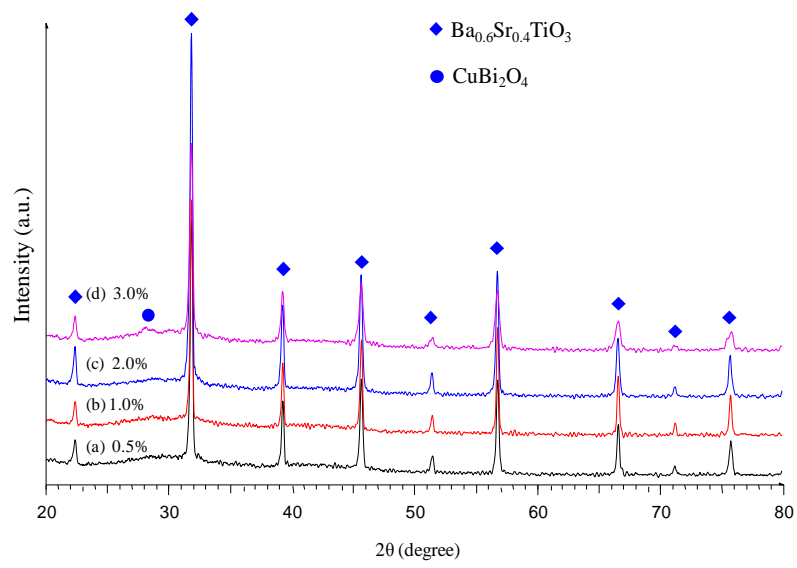

Figure 2. X-ray diffraction spectra for BSTC ceramics sintered at $9500^{\circ} \mathrm{C}$ and doped with various $\mathrm{Bi}_{2} \mathrm{O}_{3}$ concentrations: (a) $0.5 \mathrm{wt} \%$; (b) $1.0 \mathrm{wt} \%$; (c) $2.0 \mathrm{wt} \%$ and (d) $3.0 \mathrm{wt} \%$.

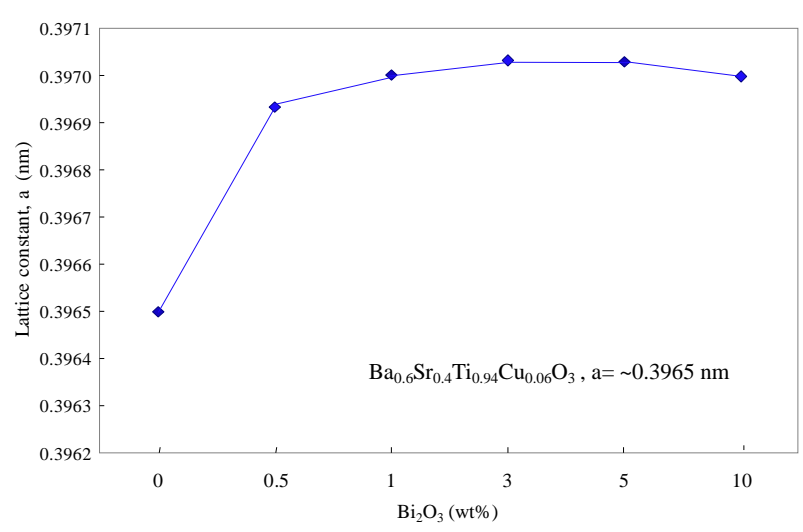

Figure 3. The variation of lattice parameter with amounts of $\mathrm{Bi}_{2} \mathrm{O}_{3}$ added into BSTC ceramics.
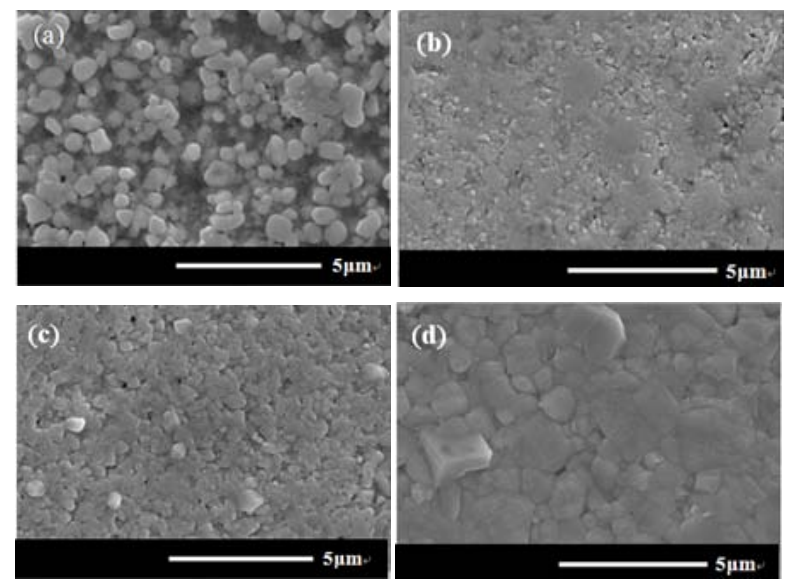

Figure 4. SEM micrographs of the BSTC ceramics with (a) $0 \mathrm{wt} \%$, (b) $0.5 \mathrm{wt} \%$, (c) $1.0 \mathrm{wt} \%$ and (d) $3.0 \mathrm{wt} \% \mathrm{Bi}_{2} \mathrm{O}_{3}$ addition and sintered at $950^{\circ} \mathrm{C}$ for $30 \mathrm{~min}$.

relative density of BSTC ceramics is discussed below. The effect of microwave sintering temperature on microstructure was also observed. SEM micrographs of the 
polished surfaces of the $1 \mathrm{wt} \% \mathrm{Bi}_{2} \mathrm{O}_{3}$-doped BSTC specimens are shown in Figures 5(a)-(c), for sintering at 900, 950, and $1000^{\circ} \mathrm{C}$, respectively. In Figure 5(a), it can be seen that the BSTC ceramic with $1 \mathrm{wt} \% \mathrm{Bi}_{2} \mathrm{O}_{3}$ addition sintered with microwave heating at $900^{\circ} \mathrm{C}$ is rather porous, therefore the densification of the ceramic is insufficient. As the sintering temperature increases, the size and number of voids in the sintered specimen is considerably reduced, as shown in Figures 5(b) and (c).

For BSTC with 3 wt $\% \mathrm{Bi}_{2} \mathrm{O}_{3}$ addition, we observed a microstructure with a significant amount of abnormal grains as shown in Figures 4(d) and 5(c). According to the XRD spectra shown in Figure 2, the composition of the secondary phase should be $\mathrm{CuBi}_{2} \mathrm{O}_{4}$ at $\mathrm{Bi}_{2} \mathrm{O}_{3}>2 \mathrm{wt} \%$. Energy dispersive spectroscopy (EDS) was used to clarify the issue, and the results of BSTC ceramic with $3 \mathrm{wt} \%$ $\mathrm{Bi}_{2} \mathrm{O}_{3}$ addition sintered at $950^{\circ} \mathrm{C}$ are shown in Figure 6 . Compared with the matrix phase (Figure 6(a)), the abnormal grains have higher signal intensities in $\mathrm{Cu}$ and $\mathrm{Bi}$ (Figure 6(b)). Moreover, the X-ray diffraction analysis in the previous section clearly shows that the formation of the $\mathrm{CuBi}_{2} \mathrm{O}_{4}$ phase was preferred at $\mathrm{Bi}_{2} \mathrm{O}_{3}>2 \mathrm{wt} \%$. It is therefore believed that the abnormal grains are composed of $\mathrm{CuBi}_{2} \mathrm{O}_{4}$.

\subsection{Density and Dielectric Properties of the Sintered Ceramics}

As described in the experimental section, the BSTC ceramics with different $\mathrm{Bi}_{2} \mathrm{O}_{3}$ additions were sintered in air at temperatures ranging from $900^{\circ} \mathrm{C}$ to $1000^{\circ} \mathrm{C}$ for 30 min. Figure 7 shows the bulk density of the BSTC ceramics as functions of $\mathrm{Bi}_{2} \mathrm{O}_{3}$ content and sintering temperature. The bulk density of the BSTC increased at higher sintering temperatures and $\mathrm{Bi}_{2} \mathrm{O}_{3}$ addition. The theoretical density of the $\mathrm{B}_{0.6} \mathrm{Sr}_{0.4}\left(\mathrm{Ti}_{0.94} \mathrm{Cu}_{0.06}\right) \mathrm{O}_{3}$ ceramics is approximately $5.69 \mathrm{~g} / \mathrm{cm}^{3}$ (based on a CuO density of $6.3 \mathrm{~g} / \mathrm{cm}^{3}$ ) [14]. The BSTC ceramics with $0.5 \mathrm{wt} \%$ $\mathrm{Bi}_{2} \mathrm{O}_{3}$ addition can be sintered to over $96 \%$ of the theoretical density (i.e. $5.46 \mathrm{~g} / \mathrm{cm}^{3}$, at $950^{\circ} \mathrm{C}$ for $30 \mathrm{~min}$ ). However, the influence of sintering temperature on the bulk density of the BSTC ceramics depends on the amounts of $\mathrm{Bi}_{2} \mathrm{O}_{3}$ addition, so the microwave sintering temperature of BSTC can be reduced to $950^{\circ} \mathrm{C}$ by increasing the glass forming content and adopting correct BSTC ceramic composition.

It is well known, pure BSTC ceramic has to be sintered at $\sim 1150^{\circ} \mathrm{C}$ for several hours, therefore BSTC ceramics with a small amount of $\mathrm{Bi}_{2} \mathrm{O}_{3}$ addition using microwave heating can increase the density of BSTC ceramics at $950^{\circ} \mathrm{C}$. Related results reported by other investigators $[13,19]$ show that the $\mathrm{Bi}_{2} \mathrm{O}_{3}$ assists in the densification of the BST dielectrics through liquid-phase sintering. It is also interesting to note that the sintered ce-

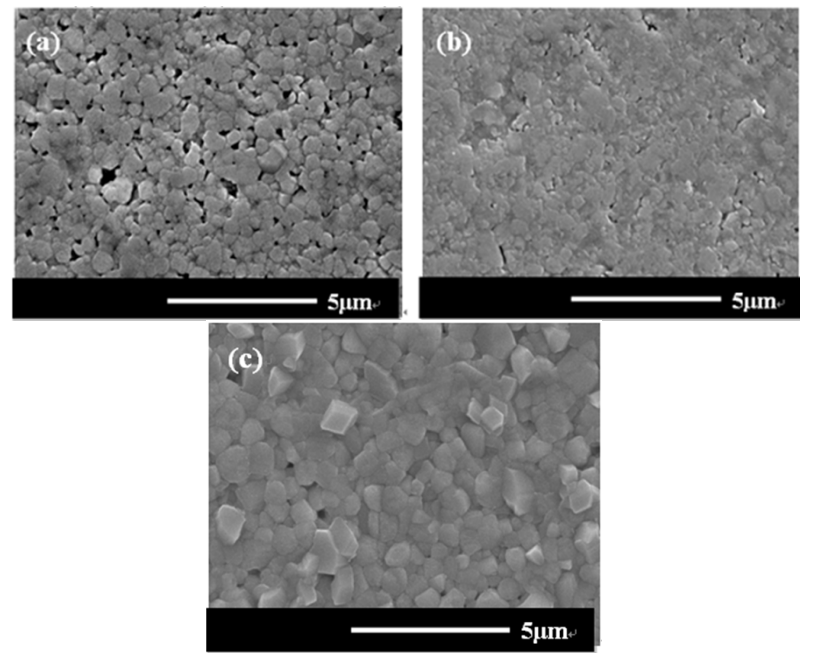

Figure 5. SEM micrographs of the BSTC ceramics with 1 wt $\% \mathrm{Bi}_{2} \mathrm{O}_{3}$ addition sintered at (a) $900^{\circ} \mathrm{C}$ (b) $950^{\circ} \mathrm{C}$ and (c) $1000^{\circ} \mathrm{C}$ for $30 \mathrm{~min}$.

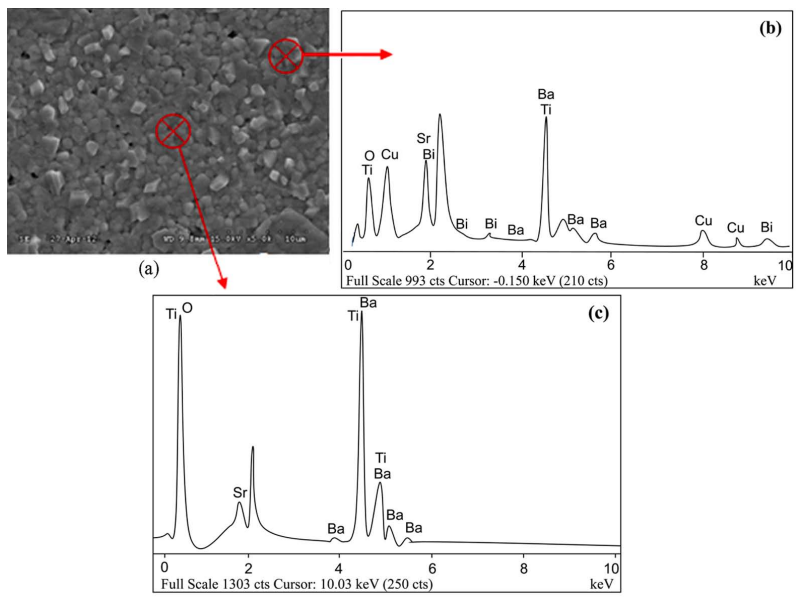

Figure 6. The BSTC ceramic with 3 wt $\% \mathrm{Bi}_{2} \mathrm{O}_{3}$ addition sintered at $950^{\circ} \mathrm{C}$, where: (a) morphology; (b) EDS of secondary phase; (c) EDS of the matrix.

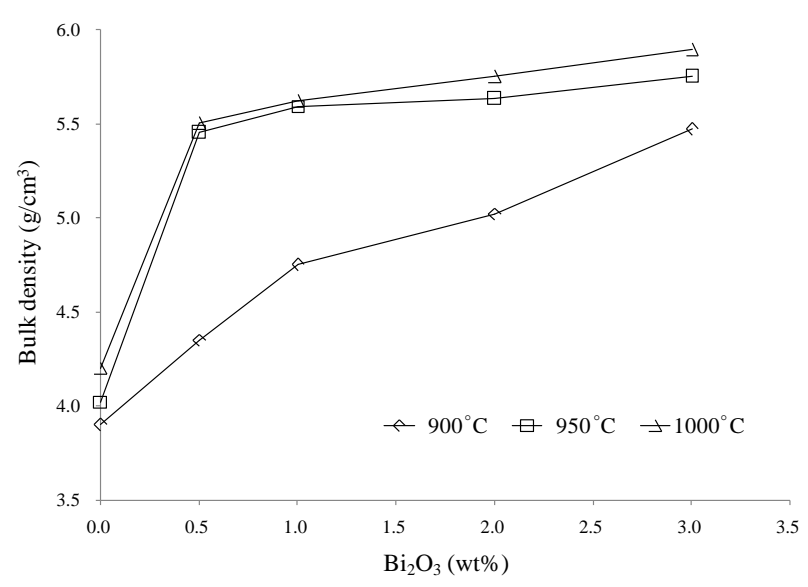

Figure 7. Bulk densities of BSTC ceramics with different $\mathrm{Bi}_{2} \mathrm{O}_{3}$ addition as a function of sintering temperature. 
ramics with the highest bulk density is the ceramics with the greatest amount of $\mathrm{Bi}_{2} \mathrm{O}_{3}$ addition at $1000^{\circ} \mathrm{C}$. In fact, the addition of $3 \mathrm{wt} \% \mathrm{Bi}_{2} \mathrm{O}_{3}$ to the BSTC ceramics that were sintered at $1000^{\circ} \mathrm{C}$ has resulted in the highest density among the sintered specimens. The reason for this is that overdoped $\mathrm{Bi}_{2} \mathrm{O}_{3}$ did not become volatile or form an appropriate amount of the liquid phase; it remained in the specimens and formed a secondary phase. According to SEM morphology and XRD analysis, the secondary phase of $\mathrm{CuBi}_{2} \mathrm{O}_{4}$ increased significantly with greater $\mathrm{Bi}_{2} \mathrm{O}_{3}$ additions. Hasegawa et al. [20] reported that the $\mathrm{CuBi}_{2} \mathrm{O}_{4}$ with melting point of $600^{\circ} \mathrm{C}$ and density of 8.5 $\mathrm{g} / \mathrm{cm}^{3}$ was effective for low-temperature sintering of Ba$\mathrm{TiO}_{3}$. Therefore, the bulk density of the BSTC ceramic can be increased when more $\mathrm{CuBi}_{2} \mathrm{O}_{4}$ forms in the samples.

The dielectric constant $\left(\varepsilon_{r}\right)$ of $\mathrm{Bi}_{2} \mathrm{O}_{3}$-doped BSTC ceramics as functions of microwave sintering temperatures and amount of $\mathrm{Bi}_{2} \mathrm{O}_{3}$ addition was measured at $1 \mathrm{MHz}$ at ambient temperature with the results shown in Figure 8(a). The dielectric constant of the BSTC ceramics increased with sintering temperature. The dielectric constants of the samples increased with the amount of $\mathrm{Bi}_{2} \mathrm{O}_{3}$ addition, and reached a maximum value at $0.5 \mathrm{wt} \%$ at $950^{\circ} \mathrm{C}$ sintering, then gradually decreased with increasing amounts of $\mathrm{Bi}_{2} \mathrm{O}_{3}$. In addition, the dielectric constant of the sample with $0.5 \mathrm{wt} \% \mathrm{Bi}_{2} \mathrm{O}_{3}$ sintered at $950^{\circ} \mathrm{C}$ was $\sim 3756$, higher than that of the sample with $1 \mathrm{wt} \% \mathrm{Bi}_{2} \mathrm{O}_{3}$ ( 2002). The reason for this is due to the decrease of lattice strain as shown in Figure 3, a small amount of $\mathrm{Bi}_{2} \mathrm{O}_{3}$ addition led to $\mathrm{Cu}^{2+}$ precipitation from the grain in BSTC materials. When $\mathrm{Cu}$ substitutes into Ti sites in the perovskite $\mathrm{ABO}_{3}$ structure, it creates lattice strain and oxygen vacancies. Preethi et al. [21] reported that the distortion of the crystalline lattice with respect to a decrease in the ionic radii might be also the reason for the increase in dielectric constant. Figure 8(b) shows the dielectric loss $(\tan \delta)$ of the BSTC ceramics at $1 \mathrm{MHz}$ as functions of sintering temperatures and amount of $\mathrm{Bi}_{2} \mathrm{O}_{3}$ addition. Similarly, the evolution of the dielectric loss of $\mathrm{Bi}_{2} \mathrm{O}_{3}$-doped BSTC ceramics reached a minimum at 0.5 $\mathrm{wt} \%$ and $950^{\circ} \mathrm{C}$ sintering temperature, and then increased gradually with increasing $\mathrm{Bi}_{2} \mathrm{O}_{3}$ content. However, the secondary phases exist for BSTC ceramics doped with $\mathrm{Bi}_{2} \mathrm{O}_{3}$, a decrease in dielectric constant is mainly associated with the formation of the second phase, $\mathrm{CuBi}_{2} \mathrm{O}_{4}$ phase, that has a lower dielectric constant in comparison with that of BSTC.

Measurement of the electrical properties over a temperature range of $-55^{\circ} \mathrm{C}-125^{\circ} \mathrm{C}$ enabled the Curie peak at the Curie temperature, Tc, to be observed and also gave an idea of the possible effects of temperature variation (i.e. in the region of room temperature which is im-
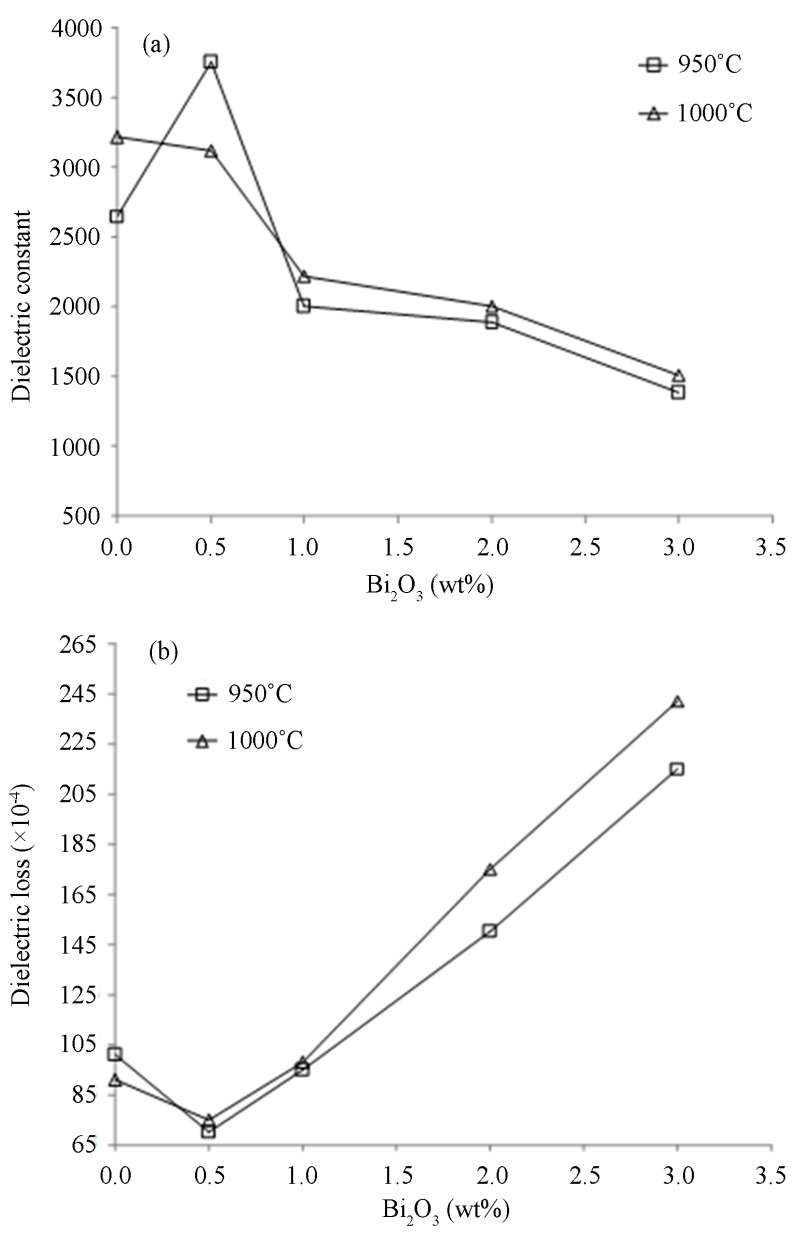

Figure 8. The dielectric constant and dielectric loss of BSTC ceramics with different $\mathrm{Bi}_{2} \mathrm{O}_{3}$ addition as a function of sintering temperature.

portant for most applications) [22]. The dielectric constant as a function of temperature at $1 \mathrm{MHz}$ for BSTC with different levels $\mathrm{Bi}_{2} \mathrm{O}_{3}$ doping are shown in Figure 9, all the samples were sintered at $950^{\circ} \mathrm{C}$. The dielectric constant decreased with increasing amounts of $\mathrm{Bi}_{2} \mathrm{O}_{3}$. The reason for this is that larger amounts of $\mathrm{Bi}_{2} \mathrm{O}_{3}$ led to the formation of a second phase. So it will be helpful to decrease the distortion of the crystal lattice and release the inner stress caused by precipitating with $\mathrm{CuBi}_{2} \mathrm{O}_{4}$ secondary phases, result in the decrease of dielectric constant.

\section{Conclusion}

The effect of the addition of $\mathrm{Bi}_{2} \mathrm{O}_{3}$ and microwave sintering on phase evolution, microstructure and dielectric properties of $\mathrm{B}_{0.6} \mathrm{~S}_{0.4}\left(\mathrm{Ti}_{0.94} \mathrm{Cu}_{0.06}\right) \mathrm{O}_{3}$ ceramics has been investigated. It was discovered that adding $\mathrm{Bi}_{2} \mathrm{O}_{3}$ to BSTC ceramics by microwave heating can lower the sintering temperature from $1150^{\circ} \mathrm{C}$ to $950^{\circ} \mathrm{C}$ and in- 


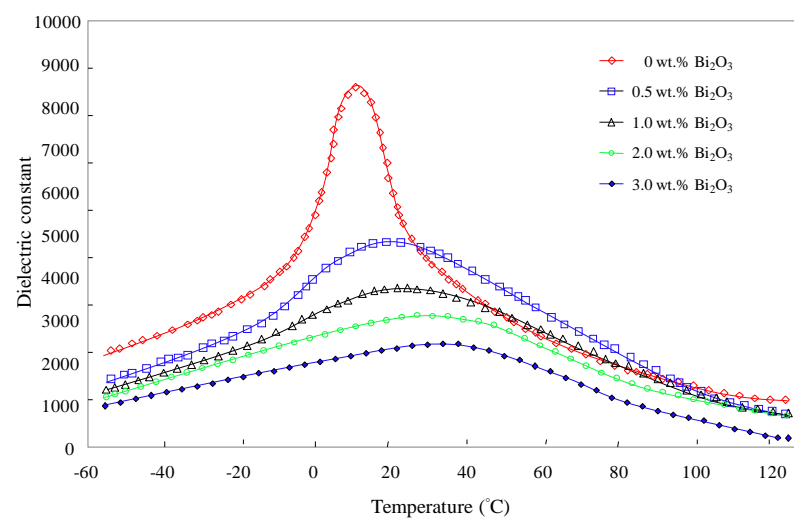

Figure 9. Temperature dependence of permittivity and dielectric loss of BSTC ceramics with different $\mathrm{Bi}_{2} \mathrm{O}_{3}$ addition. Permittivity and dielectric loss were measured at $1 \mathrm{MHz}$.

creases the bulk density of the sintered ceramics. An Xray diffraction examination of the products indicated that they consist mainly of a $\mathrm{Ba}_{0.6} \mathrm{Sr}_{0.4} \mathrm{TiO}_{3}$ crystalline phase with a $\mathrm{CuBi}_{2} \mathrm{O}_{4}$ as secondary phase, which formed as a result of $\mathrm{Bi}_{2} \mathrm{O}_{3}$ addition. A BSTC ceramics formed by adding $0.5 \mathrm{wt} \% \mathrm{Bi}_{2} \mathrm{O}_{3}$ and microwave heating at $950^{\circ} \mathrm{C}$ in air for $2 \mathrm{~h}$ gives a permittivity, $\varepsilon_{r}=3756, \tan \delta=7 \times$ $10^{-3}$ and a bulk density $>96 \%$ of theoretical.

\section{REFERENCES}

[1] J. A. Basmajian and R. C. Devries, "Phase Equilibria in the System $\mathrm{BaTiO}_{3}-\mathrm{SrTiO}_{3}$," Journal of the American Ceramic Society, Vol . 40, No. 11, 1957, pp. 373-376. http://dx.doi.org/10.1111/j.1151-2916.1957.tb12556.x

[2] D. Kolar, M. Trontelj and Z. Stadler, "Influence of Interdiffusion on Solid Solution Formation and Sintering in the System $\mathrm{BaTiO}_{3}-\mathrm{SrTiO}_{3}$," Journal of the American Ceramic Society, Vol. 65, No. 10, 1982, pp. 470-474. http://dx.doi.org/10.1111/j.1151-2916.1982.tb10335.x

[3] U. Syamaprasad, R. K. Galgali and B. C. Mohanty, "Dielectric Properties of the $\mathrm{Ba}_{1-\chi} \mathrm{Sr}_{\chi} \mathrm{TiO}_{3}$ System," Materials Letters, Vol. 7, 1988, pp. 197-200.

http://dx.doi.org/10.1016/0167-577X(88)90009-2

[4] G. W. Dietz, M. Schumacher, R. Waser, S. K. Streiffer, C. Basceri and A. I. Kingon, "Leakage Currents in $\mathrm{Ba}_{0.7} \mathrm{Sr}_{0.3} \mathrm{TiO}_{3}$ Thin Films for Ultrahigh-Density Dynamic Random Access Memories,” Journal of Applied Physics, Vol. 82, No. 5, 1997, pp. 2359-2364. http://dx.doi.org/10.1063/1.366045

[5] X. F. Liang, W. B. Wu and Z. G. Meng, "Dielectric and Tunable Characteristics of Barium Strontium Titanate Modified with $\mathrm{Al}_{2} \mathrm{O}_{3}$ Addition," Materials Science and Engineering, Vol. B99, 2003, pp. 366-369.

[6] T. Hu, H. Jantunen, A. Uusimäki and S. Leppävuori, " $\mathrm{Ba}_{0.7} \mathrm{Sr}_{0.3} \mathrm{TiO}_{3}$ Powders with $\mathrm{B}_{2} \mathrm{O}_{3}$ Additive Prepared by the Sol-Gel Method for Use as Microwave Material," Materials Science in Semiconductor Processing, Vol. 5, 2002, pp. 215-221.
http://dx.doi.org/10.1016/S1369-8001(02)00076-8

[7] F. Zimmermann, M. Voigts, C. Weil, R. Jakoby, P. Wang, W. Menesklou and E. Ivers-Tiffée, "Investigation of Barium Strontium Titanate Thick Films for Tunable Phase Shifters," Journal of the European Ceramic Society, Vol. 21, 2001, pp. 2019-2023. http://dx.doi.org/10.1016/S0955-2219(01)00164-9

[8] R. Balachandran, B. H. Ong, H. Y. Wong, K. B. Tan and M. Muhamad Rasat, "Dielectric Characteristics of Barium Strontium Titanate Based Metal Insulator Metal Capacitor for Dynamic Random Access Memory Cell,” International Journal of Electrochemical Science, Vol. 7, 2012, pp. 11895-11903.

[9] S. M. Rhim, S. Hong, H. Bak and O. K. Kim, "Effects of $\mathrm{B}_{2} \mathrm{O}_{3}$ addition on the dielectric and ferroelectric Properties of $\mathrm{Ba}_{0.7} \mathrm{SR}_{0.3} \mathrm{TiO}_{3}$ Ceramics," Journal of the American Ceramic Society,Vol. 83, No. 5, 2000, pp. 11451148.

http://dx.doi.org/10.1111/j.1151-2916.2000.tb01345.x

[10] H. Jantunen, R. Rautioaho, A. Uusimäki and S. Leppävuori, "Compositions of $\mathrm{MgTiO}_{3}-\mathrm{CaTiO}_{3}$ Ceramic with Two Borosilicate Glasses for LTCC Technology," Journal of the European Ceramic Society, Vol. 20, 2000, pp. 2331-2336.

http://dx.doi.org/10.1016/S0955-2219(00)00145-X

[11] Y. C. Lee and W. H. Lee, "Effect of Glass Addition on the Microwave Dielectric Properties of $\mathrm{Zn}_{0.95} \mathrm{Mg}_{0.05} \mathrm{TiO}_{3}+$ $0.25 \mathrm{TiO}_{2}$ Ceramics,” Japanese Journal of Applied Physics, Vol. 44, No. 4A, 2005, pp. 1838-1843. http://dx.doi.org/10.1143/JJAP.44.1838

[12] B. Wu, L. G. Zhang and X. Yao, "Low Temperature Sintering of $\left(\mathrm{Ba}_{\mathrm{x}} \mathrm{Sr}_{1-\mathrm{x}}\right) \mathrm{TiO}_{3}$ Glass-Ceramic," Ceramics International, Vol. 30, No. 7, 2004, pp. 1757-1761. http://dx.doi.org/10.1016/j.ceramint.2003.12.130

[13] J. Q. Qi, Z. L. Gui, Y. L. Wang, Y. J. Wu and L. T. Li, "Difference of $\mathrm{Bi}_{2} \mathrm{O}_{3}$ Doping Effect between Vapor Process and Solid Process on $\mathrm{Ba}_{1-\chi} \mathrm{Sr}_{x} \mathrm{TiO}_{3}$ Semiconducting Ceramics," Materials Science and Engineering, Vol. B95, No. 3, 2002, pp. 283-286.

[14] M. Valant and D. Suvorov, "Low-Temperature Sintering of $\left(\mathrm{Ba}_{0.6} \mathrm{Sr}_{0.4}\right) \mathrm{TiO}_{3}$," Journal of the American Ceramic Society, Vol. 87, No. 7, 2004, pp. 1222-1226. http://dx.doi.org/10.1111/j.1151-2916.2004.tb07716.x

[15] H. Fukushima, H. Mori, T. Hatanaka and M. Matsui, "Properties and Microstructure of PZT Ceramics Sintered by Microwave,” Journal of the Ceramic Society of Japan, Vol. 103, No. 210, 1995, pp. 1011-1015. http://dx.doi.org/10.2109/jcersj.103.1011

[16] Ying-Chieh Lee and Yen-Lin Huang, "Effects of $\mathrm{CuO}$ Doping on Microstructural and Dielectric Properties of the $\mathrm{Ba}_{0.6} \mathrm{Sr}_{0.4} \mathrm{TiO}_{3}$ Ceramics," Journal of the American Ceramic Society, Vol. 92, No. 11, 2009, pp. 2661-2667. http://dx.doi.org/10.1111/j.1551-2916.2009.03266.x

[17] S. B. Herner, F. A. Selmi, V. V. Varadan and V. K. Varadan, "The Effect of Various Dopants on the Dielectric Properties of Barium Strontium Titanate,” Materials Letters, Vol. 15, 1993, pp. 317-324.

http://dx.doi.org/10.1016/0167-577X(93)90087-E 
[18] A. R. Babu and A. V. Prasadarao, "Effect of Copper Substitution on the Microstructure and Ferroelectric Properties of Barium Titanate,” Journal of Materials Science Letters, Vol. 16, No. 4, 1997, pp. 313-315. http://dx.doi.org/10.1023/A:1018565504963

[19] H. T. Jiang, J. W. Zhai, J. J.Zhang and X. Yao, "Dielectric Properties of Low-Temperature Sintered $\mathrm{Ba}_{0.6} \mathrm{Sr}_{0.4} \mathrm{TiO}_{3}$ Ceramics by Addition of $\mathrm{Bi}_{2} \mathrm{O}_{3}$-CuO Mixed Oxides," Key Engineering Materials, Vol. 421-422, 2010, pp. 61-64. http://dx.doi.org/10.4028/www.scientific.net/KEM.421-4 22.61

[20] T. Hasegawa, "Dielectric Properties and Microstructures of Low-Temperature-Sintered $\mathrm{BaTiO}_{3}$-Based Ceramics with $\mathrm{CuBi}_{2} \mathrm{O}_{4}$ Sintering Aid," Japanese Journal of Applied Physics, Vol. 45, No. 9B, 2006, pp. 7360-7364. http://dx.doi.org/10.1143/JJAP.45.7360

[21] T. M. Preethi and R. Ratheesh, "Synthesis and Dielectric Properties of a New Class of $\mathrm{MX}_{6} \mathrm{Ti}_{6} \mathrm{O}_{19}(\mathrm{M}=\mathrm{Ba}$, Sr and $\mathrm{Ca} ; \mathrm{X}=\mathrm{Mg}$ and Zn) Ceramics,” Materials Letters, Vol. 57, 2003, pp. 2545-2552. http://dx.doi.org/10.1016/S0167-577X(02)01309-5

[22] L. Ramajo, M. Reboredo and M. Castro, "Dielectric Response and Relaxation Phenomena in Composites of Epoxy Resin with $\mathrm{BaTiO}_{3}$ Particles,” Composites, Part A, Vol. 36, 2005, pp. 1267-1274.

http://dx.doi.org/10.1016/j.compositesa.2005.01.026 